\title{
AN ASSESSMENT OF DISAMIDE, A NEW ORAL DIURETIC
}

\author{
Cecil Symons, M.D., M.R.C.P. \\ First Assistant, Cardiac Department, \\ AND \\ KathleEN BARbeR, M.B., M.R.C.P. \\ Medical Registrar, \\ The Royal Free Hospital
}

5-chloro-2 : 4-disulphamyl toluene (Disamide) is a recently introduced oral diuretic. Experimentally in animals this substance possesses a powerful diuretic action closely resembling that of chlorothiazide. ${ }^{1}$ In addition, there is some similarity of action to acetazolamide as the drug appears to inhibit the action of carbonic anhydrase.

Highly effective and relatively non-toxic oral diuretics are in such frequent use today that any new substance must possess powerful or specifically useful properties before it can be routinely prescribed. Any trial should include a comparison of the effectiveness of the new drug with one of the known modern diuretics. We report the results of a trial of Disamide in the treatment of patients with congestive cardiac failure in which hydrochlorothiazide was used as the diuretic for comparison.

\section{Procedure}

A single dose of Disamide was given to two normal subjects. The diet and fluid intake for the preceding day were repeated on the day the drug was taken. On both days urine and electrolyte output and urine $p \mathrm{H}$ were measured two hourly for the first 12 hours of the 24 -hour period.

Disamide was given to 21 in-patients (I I males, Io females) in congestive cardiac failure. Oedema was present in some degree in each case. The age range was 34-75 years with an average of 62.7 years. Eight patients had ischaemic or degenerative heart disease, five cor pulmonale, five hypertensive heart disease, two rheumatic heart disease and one had cardiomyopathy. Of these patients, six were given Disamide on alternate days (Group I); the rest had hydrochlorothiazide alternating with Disamide. (Groups 2 and 3.)

Patients in Group I were on a low sodium diet ( 0.5 g. sodium daily) and the others on a diet containing approximately $5 \mathrm{~g}$. sodium chloride

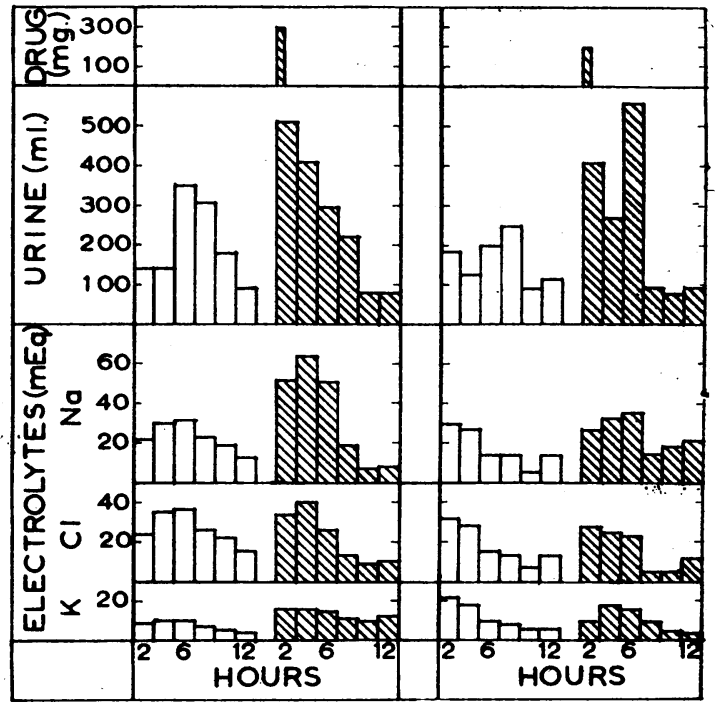

FIG. 1.-Effect of Disamide (300 mg. and $200 \mathrm{mg}$. respectively), given to two normal subjects, on volume of urine and electrolyte excretion. Twohourly outputs are shown for a period of 12 hours on two successive days with identical diet and fluid intake (cross-hatched blocks $=$ Disamide).

per day. Fluid intake was not restricted and the urine was collected over a 24-hour period. Where possible patients were weighed daily.

Disamide was also given to 18 other cardiac patients (including I I out-patients) who needed oral diuretic therapy. The out-patients were seen at approximately two-weekly intervals.

Sodium and potassium were estimated by flame photometry, chlorides by Schales and Schales method $\mathrm{d}^{3}$ and urine $p \mathrm{H}$ by Cambridge $p \mathrm{H}$ meter. Serum electrolytes were estimated at least once weekly in in-patients, and frequently in out- 
TABLE I

Mean 24-hour Urine and Sodium Output of Patients in Group I, given Disamide on Alternate Days

\begin{tabular}{|c|c|c|c|c|c|c|c|c|}
\hline \multirow{2}{*}{$\begin{array}{l}\text { Case } \\
\text { No. }\end{array}$} & \multirow{2}{*}{$\begin{array}{c}\text { Period } \\
\text { observed } \\
\text { (days) }\end{array}$} & \multirow{2}{*}{$\begin{array}{c}\text { Disamide } \\
\text { (mg.) }\end{array}$} & \multicolumn{2}{|c|}{ Mean volumé urine (ml.) } & \multirow{2}{*}{$\begin{array}{c}\text { Increase }(\%) \\
\text { urine } \\
\text { due to } \\
\text { Disamide }\end{array}$} & \multicolumn{2}{|c|}{$\begin{array}{l}\text { Mean sodium } \\
\text { output (mEq.) }\end{array}$} & \multirow{2}{*}{$\begin{array}{l}\text { Increase }(\%) \\
\text { sodium } \\
\text { due to } \\
\text { Disamide }\end{array}$} \\
\hline & & & No drug & Disamide & & No drug & Disamide & \\
\hline $\begin{array}{c}\text { I } \\
2 \\
3 \\
4 \\
5 \\
6 \\
\text { Average }\end{array}$ & $\begin{array}{l}12 \\
14 \\
10 \\
12 \\
12 \\
16\end{array}$ & $\begin{array}{l}100 \\
100 \\
100 \\
200 \\
200 \\
300\end{array}$ & $\begin{array}{r}830 \\
1,610 \\
1,750 \\
1,270 \\
1,080 \\
1,940\end{array}$ & $\begin{array}{l}1,010 \\
1,430 \\
1,800 \\
1,480 \\
1,800 \\
2,210\end{array}$ & $\begin{array}{r}21 \\
-11 \\
3 \\
16 \\
67 \\
14 \\
18\end{array}$ & $\begin{array}{l}15 \\
63 \\
89 \\
52 \\
37 \\
76\end{array}$ & $\begin{array}{l}27 \\
44 \\
92 \\
70 \\
74 \\
97\end{array}$ & $\begin{array}{r}82 \\
-30 \\
4 \\
34 \\
98 \\
27 \\
36\end{array}$ \\
\hline
\end{tabular}

TABLE II

Mran 24-hour Urine and Sodium Output of Patients in Group 2; Disamide and Hydrochlorothiazide Givev on Alternate Days. Dose of Hydrochlorothiazide was Constant at 50 mg.

\begin{tabular}{|c|c|c|c|c|c|c|c|c|}
\hline \multirow{2}{*}{$\begin{array}{l}\text { Case } \\
\text { No. }\end{array}$} & \multirow{2}{*}{$\begin{array}{c}\text { Period } \\
\text { observed } \\
\text { (days) }\end{array}$} & \multirow{2}{*}{$\begin{array}{c}\text { Disamide } \\
\text { (mg.) }\end{array}$} & \multicolumn{2}{|c|}{$\begin{array}{l}\text { Mean volume } \\
\text { urine (ml.) }\end{array}$} & \multirow{2}{*}{$\begin{array}{l}\text { Increase } \\
(\%) \text { urine } \\
\text { due to } \\
\text { hydrochloro- } \\
\text { thiazide }\end{array}$} & \multicolumn{2}{|c|}{$\begin{array}{l}\text { Mean sodium } \\
\text { output (mEq.) }\end{array}$} & \multirow{2}{*}{$\begin{array}{l}\text { Increase }(\%) \\
\text { sodium } \\
\text { die to } \\
\text { hydrochloro- } \\
\text { thiazide }\end{array}$} \\
\hline & & & Disamide & $\begin{array}{l}\text { Hydrochloro- } \\
\text { thiazide }\end{array}$ & & Disamide & $\begin{array}{l}\text { Hydrochloro- } \\
\text { thiazide }\end{array}$ & \\
\hline $\begin{array}{c}7 \\
8 \\
9 \\
10 \\
11 \\
12 \\
-13 \\
14 \\
\text { Average }\end{array}$ & $\begin{array}{l}14 \\
12 \\
10 \\
16 \\
10 \\
10 \\
10 \\
12\end{array}$ & $\begin{array}{l}100 \\
100 \\
100 \\
200 \\
200 \\
200 \\
400 \\
400\end{array}$ & $\begin{array}{l}1,450 \\
2,030 \\
2,170 \\
1,630 \\
1,750 \\
2,810 \\
1,730 \\
2,280\end{array}$ & $\begin{array}{l}1,630 \\
2,280 \\
1,820 \\
1,410 \\
2,180 \\
2,600 \\
1,760 \\
1,690\end{array}$ & $\begin{array}{r}12 \\
12 \\
-15 \\
-13 \\
25 \\
-7 \\
2 \\
-26 \\
-1\end{array}$ & $\begin{array}{r}107 \\
183 \\
117 \\
82 \\
118 \\
126 \\
80 \\
23\end{array}$ & $\begin{array}{r}152 \\
225 \\
100 \\
87 \\
186 \\
152 \\
97 \\
29\end{array}$ & $\begin{array}{r}42 \\
23 \\
-15 \\
6 \\
68 \\
58 \\
21 \\
22 \\
28 \\
23\end{array}$ \\
\hline
\end{tabular}

TABLE III

Mean 24-hour Urine and Sodium Output of Patients in Group 3 Showing the Relative Effectiveness of 100 mg. Hydrochlorothiazide aND 300 Mg. Disamide

\begin{tabular}{|c|c|c|c|c|c|c|c|c|}
\hline \multirow{2}{*}{$\begin{array}{l}\text { Case } \\
\text { Nô. }\end{array}$} & \multicolumn{3}{|c|}{ Mean volưmè urine (ml.) } & \multirow{2}{*}{$\begin{array}{c}\text { Increase } \\
(\%) \text { urine, } \\
\text { hydrochloro- } \\
\text { thiazide/ } \\
\text { Disamide }\end{array}$} & \multicolumn{3}{|c|}{ Mean sodium output (mEq.) } & \multirow{2}{*}{$\begin{array}{c}\text { Increase (\%) sodium, } \\
\text { hydrochlorothiazide } \\
\text { Disamide }\end{array}$} \\
\hline & $\begin{array}{l}\text { No } \\
\text { drug }\end{array}$ & Disamide & $\begin{array}{c}\text { Hydrochloro }= \\
\text { thiazide }\end{array}$ & & $\begin{array}{l}\text { No } \\
\text { drug }\end{array}$ & Disamide & $\begin{array}{l}\text { Hydrochloro- } \\
\text { thiazide }\end{array}$ & \\
\hline 15 & 1,090 & 1,180 & 2,300 & 9 & 72 & 98 & 163 & 66 \\
\hline 16 & $1,25^{\circ}$ & I, & $\mathbf{i}$, & & 9 & II & I & 58 \\
\hline 17 & $\mathbf{i}, 4$ & 1,860 & 2,1 & 18 & 98 & $1 r_{4}$ & 165 & 45 \\
\hline 18 & 1,220 & 1,410 & 1,560 & II & 61 & 68 & 132 & 10 \\
\hline 19 & 1,230 & 1,240 & 1,820 & 47 & 38 & 25 & 174 & 602 \\
\hline 20 & 2,030 & 2,000 & 2,890 & 45 & 60 & 110 & $22 \mathrm{i}$ & IOI \\
\hline $\begin{array}{c}2 \mathrm{I} \\
\text { Average }\end{array}$ & 1,270 & 1,490 & 2,050 & 38 & 55 & 110 & 167 & 62 \\
\hline
\end{tabular}

Each patient observed for 18 days (for explanation see text)

patients. Blood counts and liver function tests were carried out on most patients.

\section{Observations on Normal Subjects}

One normal subject was given $200 \mathrm{mg}$. and the other $300 \mathrm{mg}$. Disamide. There was a diuresis during the first eight hours after taking the drug with an increase in sodium and chloride excretion as compared with the preceding day (Fig. I).
Potassium loss was only slightly increased. The effect of the drug was greater after the larger dose of $300 \mathrm{mg}$.

\section{Observations on Group I}

Six patients were given Disamide on alternate days. Each patient had the same dose throughout the period of study and this varied from roo$400 \mathrm{mg}$. The mean output of urine during the 


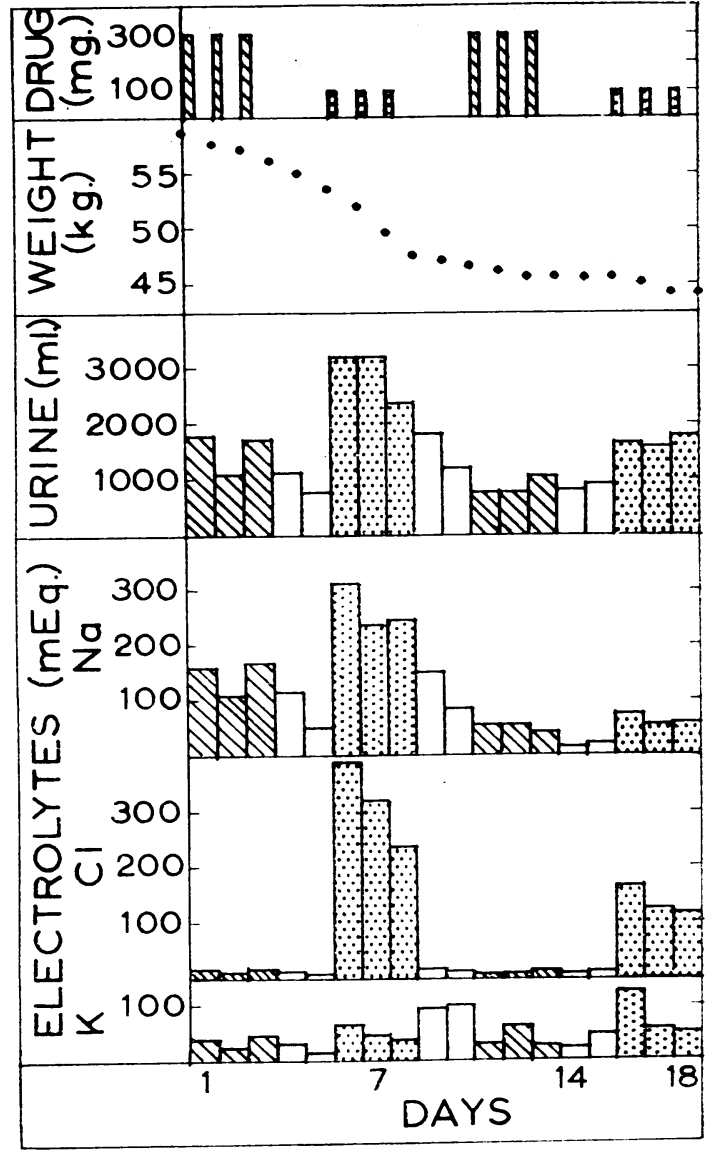

Fig. 2.-Case 15 to show typical pattern of response to Disamide and Hydrochlorothiazide (cross-hatched blocks =:= Disamide; stippled blocks $=$ Hydrochlorothiazide).

24-hour period was only slightly increased following the drug but sodium excretion was $33 \%$ higher (Table I). No consistent increase of urinary potassium was noted but both a decrease of chloride output and an alkaline urine were usual. Increasing the dose of Disamide did not appear to enhance its action.

\section{Observations on Group 2}

Eight patients were given Disamide, alternating with hydrochlorothiazide, so that Disamide was given on one day and hydrochlorothiazide on the next. Each patient had the same dose of Disamide throughout the period of study, and this varied from $100-400 \mathrm{mg}$. The dose of hydrochlorothiazide was constant at $50 \mathrm{mg}$. Both drugs appeared equally active in their effect on water loss but hydrochlorothiazide was slightly more effective in its natriuretic effect (Table II). Potassium loss was not increased with either drug.

\section{Observations on Group 3}

Seven patients were given three-day courses of Disamide (300 mg. daily) and of hydrochlorothiazide (I00 mg. daily), separated by two-day periods when no drug was given. Observations were carried out for 18 days in each patient (Table III).

Hydrochlorothiazide was considerably more effective than Disamide in respect of urine and sodium output $(40 \%$ increase in water loss and $69 \%$ increase in sodium excretion). Weight loss and potassium excretion were more obvious during the periods of treatment with hydrochlorothiazide and urinary chlorides were usually decreased when Disamide was given (Fig. 2). Compared to the days without either drug, Disamide almost always increased the output of urine and sodium.

\section{Long-Term Treatment}

roo mg. Disamide morning and noon were given to 18 other patients for periods up to three months. Two patients in this group became oedematous during a respiratory infection, but none of the others gained weight whilst taking the drug.

\section{Side Effects}

Of the 24 patients who received Disamide alone, four had severe paraesthesiae of hands, feet and face which necessitated withdrawal of the drug. Three patients complained of difficulty in expressing themselves in writing, and in six patients specifically tested there was impairment of the ability to calculate whilst taking Disamide. No associated neurological findings were noted and hypotensive reactions were not encountered. Serum electrolyte levels were consistently within normal limits.

No evidence of any renal or hepatic disorder was noted, nor any abnormality of the haematopoietic system.

\section{Discussion}

It is apparent that Disamide given in a dosage of $100-400 \mathrm{mg}$. per day has a diuretic activity comparable to $50 \mathrm{mg}$. hydrochlorothiazide; it is much less effective than $100 \mathrm{mg}$. hydrochlorothiazide. The duration of action of Disamide (over a period of eight hours), the depression of urinary chloride secretion, the occurrence of paraesthesiae and the failure to note any increase in action with increase in dosage suggests that most of the activity of Disamide is due to carbonic anhydrase inhibition. It is of interest to note that urinary chloride depression did not occur in the two normal subjects. Disamide has been shown 
to possess some anticonvulsant activity in the experimental animal, ${ }^{1}$ and this suggests that the rather disturbing cerebral effects encountered in our patients may be due to inhibition of brain carbonic anhydrase. A similar action has been described with acetazolamide. ${ }^{2}$

The main advantage of Disamide over hydrochlorothiazide is that hypokalaemia does not occur with the former drug; no potassium supplement was required even after continuous treatment for three months, but the side effects of Disamide would appear to occur too frequently to merit long-term use in congestive failure.

It is possible that Disamide, like acetazolamide, may have some place in the treatment of patients with congestive failure in conjunction with other diuretics, such as the organic mercurials or when some other action depending on carbonic anhydrase inhibition is required.

\section{Summary}

Disamide (5-chloro-2:4-disulphamyl toluene) was given to 39 patients. Twenty-one patients were in congestive cardiac failure. The effect of the drug was to increase the output of sodium but it was appreciably less effective than $100 \mathrm{mg}$. hydrochlorothiazide.

The action of Disamide resembled that of a carbonic anhydrase inhibitor particularly in its side effects.

\section{Acknowledgements}

We wish to thank Dr. Frances Gardner for permission to study her patients and for her criticism of this paper. We also wish to thank Dr. J. L. Hunt of the Medical Department of British Drug Houses for supplying Disamide.

\section{REFERENCES}

I. DAVID, A., and FELI,OWES, K. P. (1960), 7. Pharm. Pharmacol., 12, 65

2. MILLICHAP, J. G., and WOODBURY, D. M. (1955), $f$. Pharm. Exp. Therap., 113, 39.

3. SCHALES, O., and SCHALES, S. S. (1941), f. biol. Chem. 140, 879 .

\section{U N IVER S I TY O F GLASG OW}

\section{Diploma in Clinical Psychology}

A Course of Instruction over two years leading to the Diploma in Clinical Psychology will commence in July, 1960. An initial hospital attachment will be followed by a course of formal instruction covering three academic terms. The final twelve months of the course will be devoted to practical training in a Mental Hospital. A limited number of paid appointments under the Regional Hospital Board is available, permitting attendance on the course.

The fee for the full course, including examination fee, is $£ 100$. This is payable in two instalments: $£_{170}$ for the first year and $f .3 \circ$ for the second.

Applicants must be First or Second Class Honours graduates in Psychology of a British or other recognised university. Further details, application forms and regulations may be obtained from the Professor of Psychological Medicine, Southern General Hospital, Glasgow. The closing date for the submission of applications is July Ist, 1960.

\section{UNIVERSITY OF GLASGOW AND THE \\ ROYAL FACULTY OF PHYSICIANS AND SURGEONS \\ POSTGRADUATE MEDICAL EDUCATION COMMITTEE}

\section{CURRENT TRENDS IN SURGERY}

An intensive course on 'Current Trends in Surgery' will be held from September 26th to October 8th, I960. This will consist of lectures, discussions, clinical demonstrations, conferences, etc., and will be suitable as a revision course for candidates for the Final Surgical Fellowships Examinations or as a refresher course for surgeons.

The fee for the course is $\oint_{2} \mathrm{I}_{5} \mathrm{I}_{5} \mathrm{~s}$.

Further details can be obtained from:

The Convener,

Postgraduate Medical Education Committee, The University, Glasgow, W.2 